\title{
Survei Magnetotellurik (MT) dan Time Domain Electro Magnetic (TDEM) Daerah Panas Bumi Dua Saudara, Provinsi Sulawesi Utara
}

\author{
Ahmad Zarkasyi , Yadi Supriyadi, Sri Widodo \\ Pusat Sumber Daya Geoogi, Badan Geologi, KESDM
}

\begin{abstract}
Abstrak
Survei magnetotelurik telah dilakukan di daerah panas bumi, Kota Bitung, Sulawesi Utara dengan tujuan memodelkan struktur tahanan jenis bawah permukaan yang berkorelasi dengan sistem panas bumi. Desain pengukuran melingkupi manifestasi panas bumi yang muncul di beberapa titik dengan asumsi lintasan pemodelan berarah baratdaya-timurlaut. Data pengukuran diproses menggunakan algoritma Robust kemudian setelah dilakukan analisis strike dan data editing, data dimodelkan secara 2 dimensi. Interpretasi hasil pemodelan menunjukkan adanya lapisan bertahanan jenis di bawah 10 Ohmm terdeteksi sampai kedalaman sekitar 500-750 meter yang diperkirakan sebagai lapisan penudung dan disusul lapisan batuan bertahanan jenis 50-250 Ohmm di bawahnya sebagai lapisan reservoir sistem panas bumi.
\end{abstract}

Kata Kunci: Panas bumi, Magnetotellurik,

Dua Saudara geothermal prospect area is located at Sulawesi Utara Province. The geothermal system in this area is associated with Mt. Tangkoko - Batuangus volcanic activities. Geologically, quaternary rocks produced by volcanic eruption become the dominant rocks in this area. Previous research estimated that the Hot Springs in the Dua Saudara geothermal prospect area reflects a reservoir temperature about $150^{\circ} \mathrm{C}$. MT data acquisition was carried out by the Center for Geological Resources of the Geological Agency. 2-D inversion of MT data in Dua Saudara Prospect conducted to obtain the structure of rocks resistivity in this area. The result shows conductive layer $(<10 \mathrm{ohm}-\mathrm{m})$ with approximately 500-1000 meters thickness is indicated as claycap layer of Dua Saudara geothermal system which open to Mt. Tangkoko - Batuangus direction. The zone below the claycap with higher resistivity $(30-150 \mathrm{ohmm})$ is indicated as reservoir zone, while a body with high resistivity (>150 ohm-m) is interpreted as heat source which is associated with volcanic activity of Mt. Tangkoko - Batuangus

\section{PENDAHULUAN}

Daerah panas bumi berada di wilayah Kota Bitung, Provinsi Sulawesi Utara (Gambar 1). Sistem panas bumi di daerah ini diindikasikan dengan munculnya beberapa manifestasi panas bumi berupa mata air panas dengan temperatur 34-61 ${ }^{\circ} \mathrm{C}$. Lokasi manifestasi berada di sekitar lereng Gunung dan Tangkoko yang merupakan dua gunung aktif berumur Kuarter. Penyelidikan tentang kepanas bumian di daerah ini dimulai pada tahun 2013 dengan metode geologi dan geofisika.

Hasil pemetaan batuan yang dilakukan Pusat Sumber Daya Geologi menyebutkan bahwa daerah panas bumi Dua Sudara didominasi oleh lava andesit basal, aliran piroklastik dan jatuhan piroklastik Tersier hingga Kuarter (Gambar 2). Struktur sesar yang berkembang dipengaruhi oleh subduksi di bagian utara antara Lempeng Pasifik dan Asia Timur dengan arah tegasan utara-selatan. Struktur lokal yang terbentuk di sekitar Gunung Tangkoko dan Dua Sudara, berupa sesar normal dan mendatar yang berarah hampir utara-selatan dan baratdaya-timurlaut yang juga sangat dipengaruhi oleh aktifitas tektonik regional (subduksi).

Pusat Sumber Daya Geologi - Badan Geologi - Kementrian Energi dan Sumber Daya Mineral Jalan Soekarno- Hatta No 444 Bandung Jawa Barat Website: psdg.geologi.esdm.go.id/ 
Anomali gaya berat (residual) menunjukkan nilai tinggi terdapat pada bagian utara, barat, timur, dan tenggara daerah penyelidikan. Pada bagian utara diindikasikan sebagai respon satuan batuan Lava Tembaankoka yang memiliki umur pembentukan lebih muda dari Gunung Dua Sudara. Anomali tinggi di bagian barat Gunung Dua Saudara diduga respon lava berukuran tebal dan masif yang dijumpai oleh hasil geologi permukaan. Sedangkan anomali tinggi pada bagian tenggara merupakan indikasi batuan vulkanik tua Tondano yang kemungkinan bersifat masif sehingga masih memiliki nilai densitas tinggi.

Hasil penyelidikan geologi dan geofisika tahun 2013 ini menjadi acuan dalam mendesain rencana pengukuran Magnetotellurik (MT) dan TDEM. Survei MT ini diharapkan mampu memberikan informasi yang lebih detail dan jelas tentang sistem panas bumi Dua Saudara. Hasil MT akan memodelkan struktur tahanan jenis bawah permukaan yang berkorelasi dengan sistem panas bumi sehingga akan dapat menegaskan keprospekan (letak, delineasi, dan kedalaman) daerah panas bumi Dua Saudara.

\section{METODE SURVEI DAN TEORI MT}

\section{Metode Survei MT}

Metode survei magnetotellurik pada daerah panas bumi dilakukan dengan tahapan studi literatur, persiapan kerja lapangan (kalibrasi peralatan) desain survei, akuisisi, pengolahan dan pemodelan data.

Berdasarkan hasil terdahulu tentang sistem panas bumi daerah Dua Saudara maka titik pengukuran MT didesain sehingga hasil yang diharapkan tercapai. Akuisisi data pengukuran menggunakan Phoenix System dengan rentang frekuensi yang diukur $312-0,1 \mathrm{~Hz}$. Data hasil pengukuran diproses dengan menggunakan algoritma Robust. Kemudian data dikoreksi, editing dan dianalisis EM strike (rotasi).
Penentuan arah rotasi Dalam pemrosesan data MT menggunakan metode tensor impedansi untuk kuantitatifnya dan arah struktur geologi untuk kualitatifnya. Setelah proses rotasi dan editing, data yang mengalami shifting dikoreksi dengan menggunakan data TDEM. Data yang terkoreksi ini yang selanjutnya digunakan untuk pemodelan 2 dimensi.

\section{Teori Dasar MT dan TDEM}

Metode MT adalah salah satu metode geofisika yang memanfaatkan gelombang elektromagnetik. Metode ini mengukur respon bumi dalam besaran medan listrik $(E)$ dan medan magnet $(H)$ terhadap medan elektromagnetik (EM) alam. Respon tersebut berupa komponen horizontal medan magnet dan listrik bumi yang diukur pada permukaan bumi pada posisi tertentu.

Tahanan jenis dari metode ini dihitung berdasarkan perbandingan besarnya medan listrik dan medan magnet yang dikenal dengan persamaan Cagniard. Persamaan ini dihasilkan dari persamaan Maxwell dengan asumsi gelombang bidang.

$$
\rho_{a}=\frac{1}{5} f \times\left|\frac{E}{H}\right|^{2} \text {. }
$$

Dimana,

$\rho_{a}$ : tahanan jenis semu (Ohm-m)

$f$ : frekuensi $(\mathrm{Hz})$

E : Besarnya medan listrik $(\mathrm{mV} / \mathrm{km})$

$\mathrm{H}$ : Besarnya medan magnet (nT)

Tahanan jenis semu terdiri dari dua kurva seperti Rho $x y$ dan Rhoyx, kemudian dirotasi terhadap sumbu utama, bisa kedalam TE mode (medan listrik sejajar dengan strike) atau TM Mode (medan listrik tegak lurus strike).

Penetrasi kedalaman efektif dapat ditentukan dengan menggunakan persamaan di bawah ini :

$\delta=503 \times(\rho / f)^{1 / 2}$

Dimana

$$
\begin{array}{ll}
\delta & : \text { penetrasi kedalaman efektif }(\mathrm{m}) \\
\rho & : \text { tahanan jenis semu }(\mathrm{Ohm}-\mathrm{m}) \\
\mathrm{f} & : \text { frekuensi }(\mathrm{Hz})
\end{array}
$$


Ketika tahanan jenis berubah terhadap kedalaman, maka tahanan jenis semu akan berubah terhadap frekuensi, karena frekuensi tinggi tidak memiliki penetrasi yang cukup dalam, sedangkan frekuensi rendah memiliki penetrasi lebih dalam. Hal ini menunjukkan bahwa struktur tahanan jenis dari zona dangkal sampai ke zona dalam dapat dianalisis berdasarkan tinggi atau rendahnya frekuensi.

Skin depth sebagai fungsi dari frekuensi dan tahanan jenis dapat ditentukan dari persamaan berikut.

$$
\delta=\left(\frac{2}{\omega \mu \sigma}\right)^{\frac{1}{2}}=503 \sqrt{\frac{\rho}{f}}
$$

Dimana

$\delta \quad$ : skin depth $(\mathrm{m})$

$\omega \quad:(=2 \pi f)$ frekuensi sudut

$\sigma \quad$ : konduktivitas $(\mathrm{S} / \mathrm{m})$

$\mu \quad$ : permeabilitas magnet $(\mathrm{H} / \mathrm{m})$

$\rho \quad$ : tahanan jenis semu (Ohm-m)

f : frekuensi $(\mathrm{Hz})$

Metode TDEM (Time Domain Electro Magnetic) atau kadang disebut juga TEM (Transient Electro Magnetic) adalah salah satu metode geofisika yang memanfaatkan medan elektromagnetik untuk mengetahui struktur tahanan jenis bawah permukaan. Metode ini menggunakan sumber buatan dengan mengukur peluruhan tegangan transient sebagai fungsi waktu.

$$
V(t, r)=I_{0} \frac{C\left(\mu_{0} \sigma r^{2}\right)^{3 / 2}}{10 \pi^{1 / 2} t^{5 / 2}}
$$

dimana, $C=A_{r} N_{r} A_{s} N_{s} \frac{\mu_{0}}{2 \pi r^{3}}$, dan

$A_{r}=$ Luas area receiver coil $\left(\mathrm{m}^{2}\right)$

$N_{r}=$ Jumlah perputaran didalam receiver coil

$A_{s}=$ Luas area dari transmitting loop $\left(m^{2}\right)$

$N_{S}=$ Jumlah perputaran didalam transmitter loop

$t_{r}=$ Waktu yang berjalan setelah arus pada transmitter dimatikan

$\mu_{0}=$ Permeabilitas magnetik $\left(\frac{h e n r y}{m}\right)$
$V(t, r)=$ Tegangan transien

$r=$ Jari-jari dari transmitter loop $(m)$

$I_{0}=$ Arus pada transmitting loop $(A)$

Dengan mengsubtitusi $\sigma=\frac{1}{\rho}$, pada persamaan diatas, sehingga menghasilkan nilai tahanan jenis sebagai berikut:

$\rho_{a}=\frac{\mu_{0}}{4 \pi}\left[\frac{2 I_{0} A_{r} N_{r} A_{S} N_{S}}{5 t^{5 / 2} V(t, r)}\right]^{3 / 2}$

Hubungan ini mendefinisikan bahwa nilai tahanan jenis semu terhadap lamanya waktu yang berjalan setelah arus dimatikan.

\section{HASIL PENYELIDIKAN}

Jumlah titik MT dan TDEM sebanyak 35 titik dengan jarak antar titik ukur berkisar 500-1500 meter (Gambar 4). Sebaran titik melingkupi mata air panas yang diduga sebagai area keprospekan panas bumi. Kualitas data mayoritas bagus pada frekuensi tinggi $(320 \mathrm{~Hz})$ sampai dengan frekuensi sekitar $0,1 \mathrm{~Hz}$. Sedangkan frekuensi $<0,1 \mathrm{~Hz}$ kualitas data yang peroleh mulai mendapatkan noise.

Hasil analisis tensor impedansi pada semua titik magnetotelurik menghasilkan rentang arah rotasi yang dapat digunakan adalah $0^{\circ}-60^{\circ}$ derajat atau $-120^{\circ}-180^{\circ}$ (Gambar 5 kanan). Dari rentang arah tersebut digunakan rotasi dengan arah $-120^{\circ}$ karena pertimbangan analisa kualitatif (sesar geologi). Pada beberapa data terdapat shifting yang akan terkoreksi oleh data TDEM. Contoh data MT sebelum dan sesudah dilakukan koreksi statik ditunjukkan oleh Gambar 5.

Hasil pengolahan data berupa nilai tahanan jenis yang ditampilkan dalam bentuk lateral maupun vertikal. Selain model tahanan jenis ditampilkan pula tahanan jenis semu invarian yang merupakan tahanan jenis hasil penggabungan rho $_{x y}$ dan rho $_{y x}$ sebagai acuan awal atau pengontrol hasil pemodelanannya.

$\underline{\text { Tahanan Jenis Semu Invarian }}$ 
Sebaran tahanan jenis semua invarian digunakan sebagai ilustrasi awal dalam proses pemodelan. Tahanan jenis ini merupakan tahanan jenis kombinasi dari transvere electric mode (TE mode) dan transvere magnetic mode (TM mode). Gambar 6 memperlihatkan beberapa peta sebaran tahanan jenis semu yang dicuplik pada berbagai frekuensi.

Sebaran tahanan jenis di frekuensi tinggi (300 dan $100 \mathrm{~Hz}$ ) memilki rentang nilai sekitar 5-50 Ohmm dengan nilai di bawah $10 \mathrm{Ohmm}(<\log 1)$ tersebar di sekitar keberadaan mata air panas (MAP) Srawet-1, srawet-2 dan Batu Putih, kecuali MAP Pinasungkulan ( 40-50 Ohmm). Area di luar daerah tersebut nilai tahanan jenis umumnya homogen dengan nilai 30-40 Ohmm dengan liniasi kontur berarah baratlauttenggara di bagian tengah dan utara, sedangkan bagian selatan arah liniasi tidak teratur.

Nilai tahanan jenis rendah di sekitar MAP Srawet-1, Srawet-2 dan Batu Putih semakin meluas ke arah utara (arah pantai) pada frekuensi 10 dan 1 $\mathrm{Hz}$. Sedangkan area bagian tengah pada ke dua frekuensi ini memiliki nilai yang semakin meninggi dengan tren liniasi berarah baratlaut-tenggara. Pada frekuensi yang lebih rendah $(0,1$ dan $0,01 \mathrm{~Hz}$ ) nilai tahanan jenis tampak semakin seragam antara bagian utara dan selatan. Nilai tahanan jenis $<10$ Ohmm di sekitar mata air panas juga sudah tidak muncul digantikan oleh nilai tahanan jenis sekitar 30-50 Ohmm.

\section{$\underline{\text { Tahanan Jenis }}$}

Tahanan jenis dihasilkan dari pemodelan inversi. Hasil model ditampilkan dalam bentuk vertikal (penampang) dan lateral (peta sebaran). Gambar 7 dan 8 merupakan hasil pemodelan tahanan jenis di daerah Dua Saudara.

Sebaran tahanan jenis pada kedalaman 250, 500 dan 750 meter memperlihatkan liniasi kontur cendrung berarah baratlaut-tenggara. Liniasi ini mengindikasikan adana struktur sesar geologi dengan arah yang sama (Nurhadi, dkk, Tim Survei Terpadu, 2013). Pada kedalaman 1000, 1500 dan 2000 meter liniasi ini mengalami gangguan di bagian tengah dengan pola liniasi barat-timur dan baratdayatimurlaut. Perubahan ini dikarekan adanya struktur tubuh batuan beku yang lebih muda dan muncul di zona struktur bagian tengah..

Pola sebaran tahanan jenis bervariasi pada kedalaman 250- 750 meter dan pada kedalaman 1000 meter ke bawah, pola sebaran tahanan jenis mulai homogen. Tahanan jenis rendah bernilai di bawah 10 Ohmm muncul di area-area sekitar lokasi munculnya manifestasi panas bumi (MAP Srawet-1 dan 2, Pinasungkulan dan Batu Putih). Sedangkan di luar area tersebut ditempati oleh tahanan jenis bernilai sekitar 15-50 Ohmm.

Korelasi tahanan jenis rendah $<10$ Ohmm dengan batuan penyusunnya berdasarkan litologi batuan adalah batuan vulkanik tua Tondano berupa batuan piroklastik dan atau batuanbatuan yang lebih muda (vulkanik Dua Saudara dan Tembaankoka) yang telah mengalami alterasi hidrotermal. Sedangkan tahanan jenis bernilai 15-50 yang terdeteksi mulai dari kedalaman 250-1000 meter diperkirakan juga masih respon dari batuan vulkanik Tondano.yang mungkin fisiknya lebih kompak (welded).

Informasi geologi menyebutkan bahwa produk Tondano ini sebarannya cukup luas. Produk ini diterobos oleh batuan yang lebih muda di area bagian tengah (lava Tembaankoka). Tahanan jenis tinggi yang diinterpretasikan sebagai terobosan lava ini semakin tegas muncul di bagian tengah dengan bertambahnya kedalaman dengan nilai mencapai lebih dari 300 Ohmm. Sebaran tahanan jenis pada kedalaman 1500 meter ke bawah telah berpola homogen, baik nilai dan liniasinya.

\section{DISKUSI}

Pusat Sumber Daya Geologi - Badan Geologi - Kementrian Energi dan Sumber Daya Mineral Jalan Soekarno- Hatta No 444 Bandung Jawa Barat Website: psdg.geologi.esdm.go.id/ 
Sebaran tahanan jenis (Gambar 7) menunjukkan adanya lapisan batuan bertahanan jenis rendah ( $<10$ Ohmm) menempati area-area sekitar lokasi mata air panas. Lapisan batuan tersebut diperkirakan respon dari batuan yang teralterasi akibat fluida hidrotermal dan berperan sebagai lapisan penudung (caprock). Lapisan batuan teralterasi ini terdeteksi sampai kedalaman sekitar 500-750 meter (Gambar 8).

Lapisan reservoir diduga berada di lapisan batuan bertahanan jenis $>100$ Ohmm yang termodelkan di bawah lapisan bertahanan jenis rendah $(<10$ Ohmm). Berdasarkan informasi geologi, lapisan batuan tersusun dari batuan vulkanik tua yang lulus air dan sangat mungkin untuk menjadi lapisan resevoir dari sistem panas bumi Dua Saudara.

Zona pengukuran MT yang dilakukan diperkirakan berada di zona outflow. Informasi zona outflow ini didasari hasil penelitian sebelumnya. Jika area ini diasumsikan zona outflow maka besar kemungkinan resevoir ini hanya bagian dari resevoir utama atau ujung dari lidah resevoirnya. Zona resevoir ini mulai terdeteksi sekitar kedalaman 750-1000 meter dan di batasi oleh sesar geologi berarah baratlauttenggara.

Deliniasi zona prospek panas bumi Dua Saudara dengan mengacu pada hasil magnetotelurik sukar dilakukan. Hal ini dikarenakan hasil yang diperoleh mengindikasikan sistem panas bumi Dua Saudara berada di sekitar lereng Gunung Dua saudara dan Tangkoko dan memperkuat analisis sebelumnya. Sedangkan area pengukuran MT yang dilakukan ternyata berada di zona outflow dari sistem panas bumi.

Interpretasi dari peta sebaran tahanan jenis mempertegas arah area keprospekan yang membuka ke arah Gunung Dua Saudara dan Tangkoko. Hal ini didasari dari nilai tahanan jenis rendah yang membuka ke arah Tenggara yaitu Gunung Dua Saudara dan Tangkoko. Hasil penampang tahanan jenis juga mengindikasikan pola sebaran tahanan jenis di area mata air panas Srawet, Pinasungkulan dan Batu Putih berbentuk melidah sebagai indikasi awal zona outflow.

\section{KESIMPULAN}

Sebaran tahanan jenis secara lateral dari metode magnetotelurik di daerah panas bumi Dua Saudara mengindikasikan daerah prospek utama panas bumi berada atau membuka ke arah lereng Gunung Dua saudara dan Tangkoko. Sedangkan area pengukuran MT yang dilakukan berada di zona outflow dari sistem panas bumi.

Lapisan bertahanan jenis rendah di bawah 10 Ohmm diperkirakan sebagai lapisan penudung terdeteksi sampai kedalaman sekitar 500-750 meter. Lapisan batuan bertahanan jenis sekitar 50-250 Ohmm di bawah lapisan batuan bertahanan jenis rendah belum dapat dipastikan sebagai resevoir karena berada di zona outflow.

\section{UCAPAN TERIMA KASIH}

ucapan terima kasih tim penulis hantarkan kepada para staf Pusat Sumber Daya Geologi bidang panas bumi yang telah berperan serta dalam penulisan ini. Kegiatan diskusi terutama tentang informasi geologi daerah Dua Saudara sangat bermanfaat dalam interpretasi hasil MT.

\section{DAFTAR PUSTAKA}

Geothermal Departement, Basic Concept of Magnetotelluric Survey in Geothermal Fields., West Japan Engineerring Consultants, Inc.

Burger, H.R., 1992, Exploration Geophysics of shallow Sub Surface, Prentice Hall.

Telford, W.M. et al, 1982. "Applied Geophysics", Cambridge University Press. Cambridge.

Tim Survei Geofisika Terpadu Panas Bumi, 2013, 'Laporan Survei Geofisika Terpadu Daerah Panas Bumi Dua Sudara, Kota Bitung, 
Provinsi Sulawesi Utara.' Pusat Sumber Daya Geologi, Badan Geologi, Kementrian Energi dan Sumber Daya Mineral Indonesia. (Unpubl. Report)

Tim Survei Terpadu, 2013, 'Laporan Survei Terpadu Geologi dan Geokimia Daerah Panas Bumi Dua Sudara, Kota Bitung, Provinsi Sulawesi Utara.' Pusat Sumber Daya Geologi, Badan Geologi, Kementrian
Energi dan Sumber Daya Mineral Indonesia. (Unpubl. Report).

Tim Survei Magnetotellurik, 2014, Laporan Survei Magnetotellurik Daerah Panas Bumi Dua Saudara, Kota Bitung, Provinsi Sulawesi Utara, Pusat Sumber Daya Geologi, Kementrian Energi dan Sumber Daya Mineral Indonesia. (Unpubl. Report).

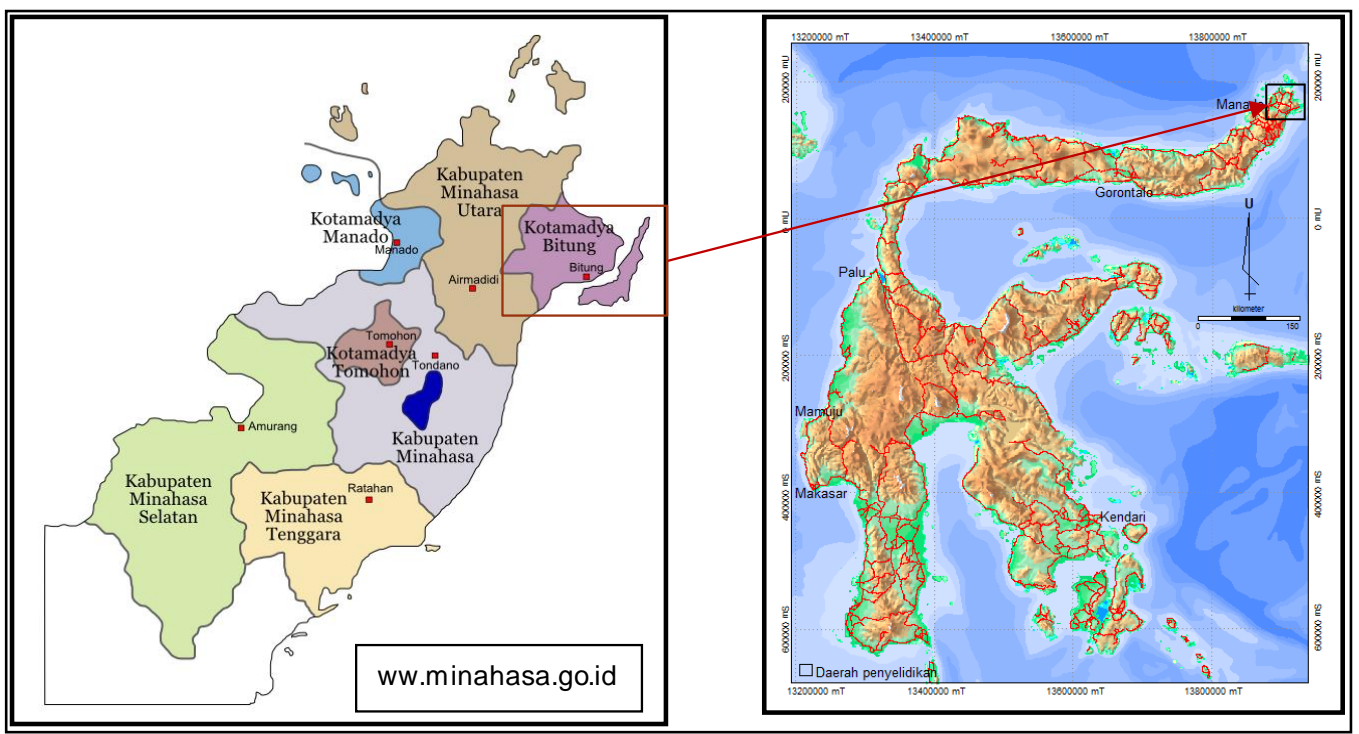

Gambar 1 Peta Lokasi daerah survey 


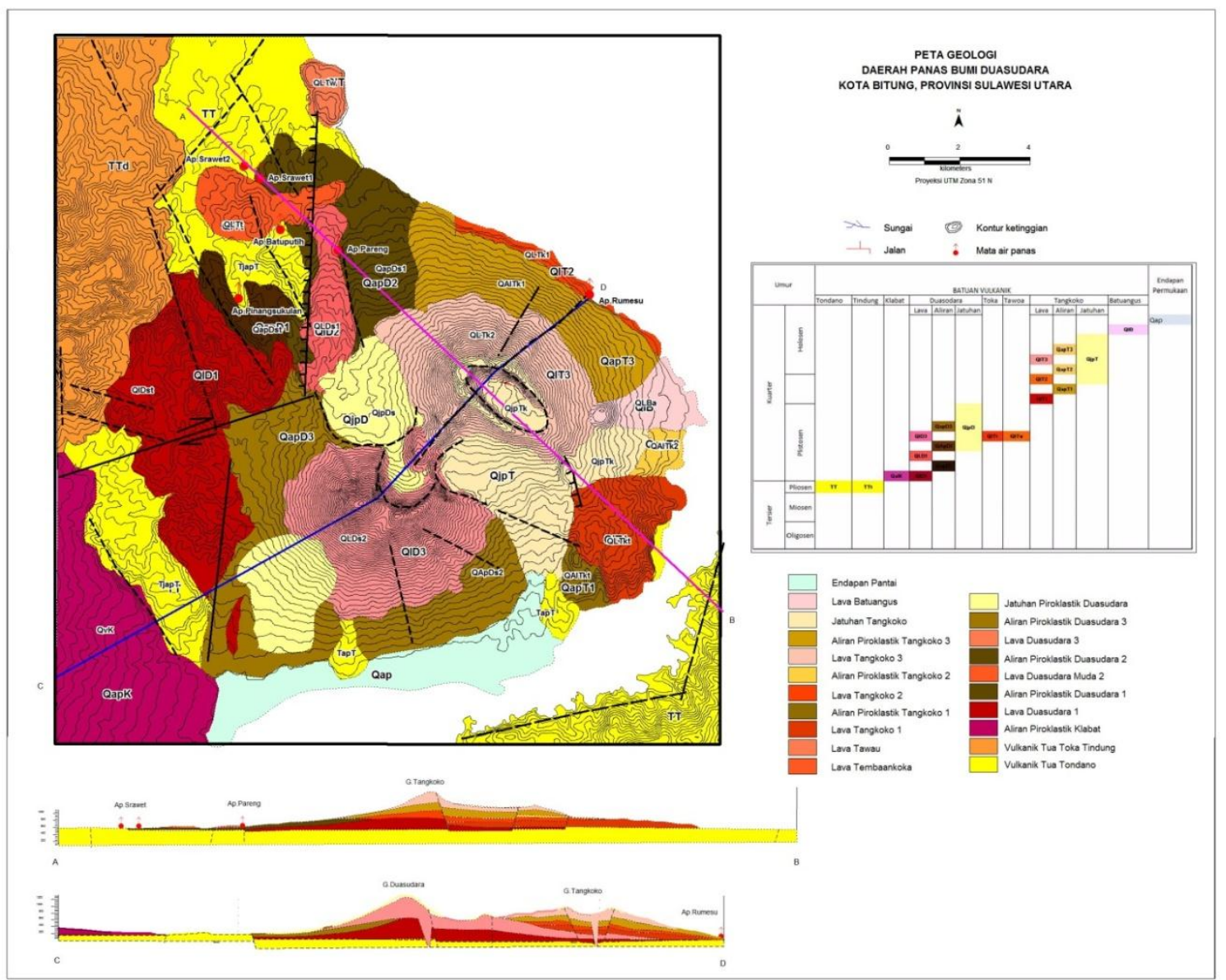

Gambar 2. Peta Geologi daerah panas bumi Dua Sudara (Survei Terpadu, PSDG 2013)

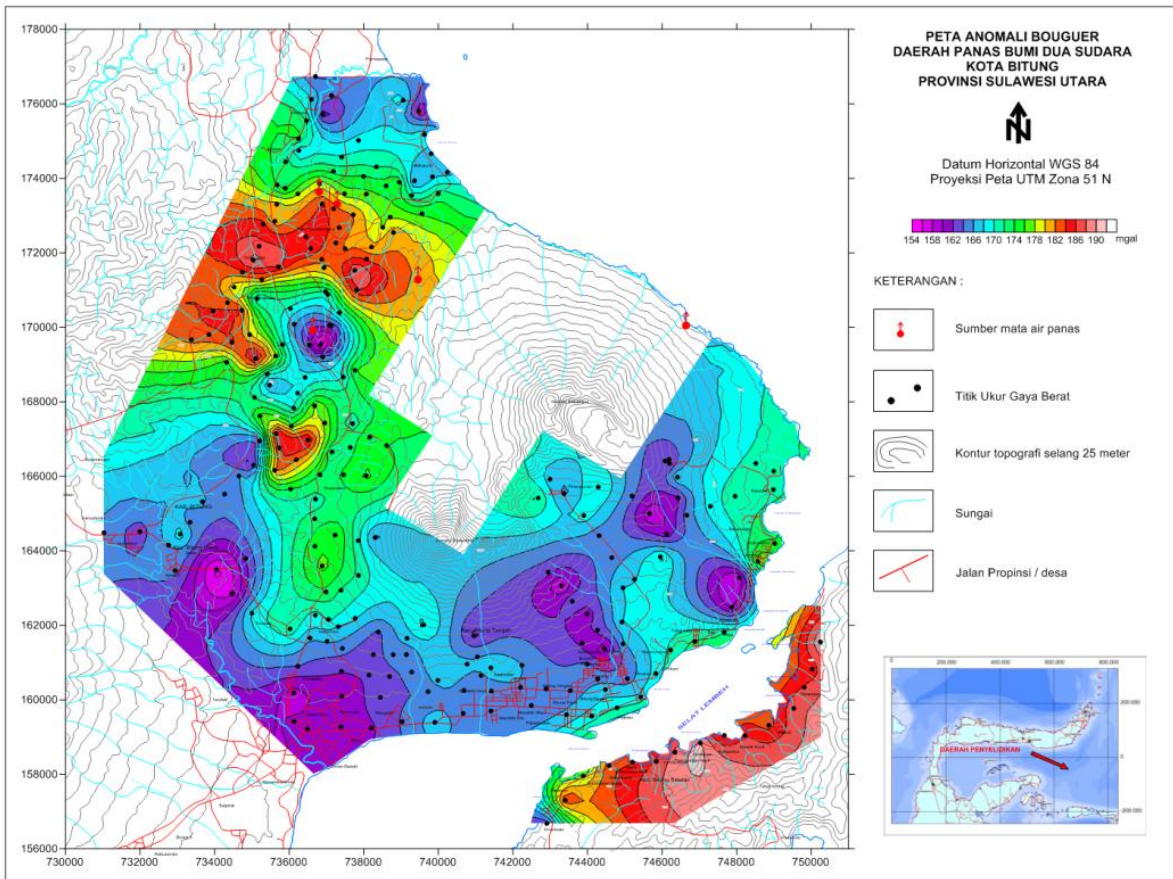

Gambar 3. Peta anomali residual (Survei Geofisika Terpadu, PSDG, 2013)

Pusat Sumber Daya Geologi - Badan Geologi - Kementrian Energi dan Sumber Daya Mineral Jalan Soekarno- Hatta No 444 Bandung Jawa Barat Website: psdg.geologi.esdm.go.id/ 


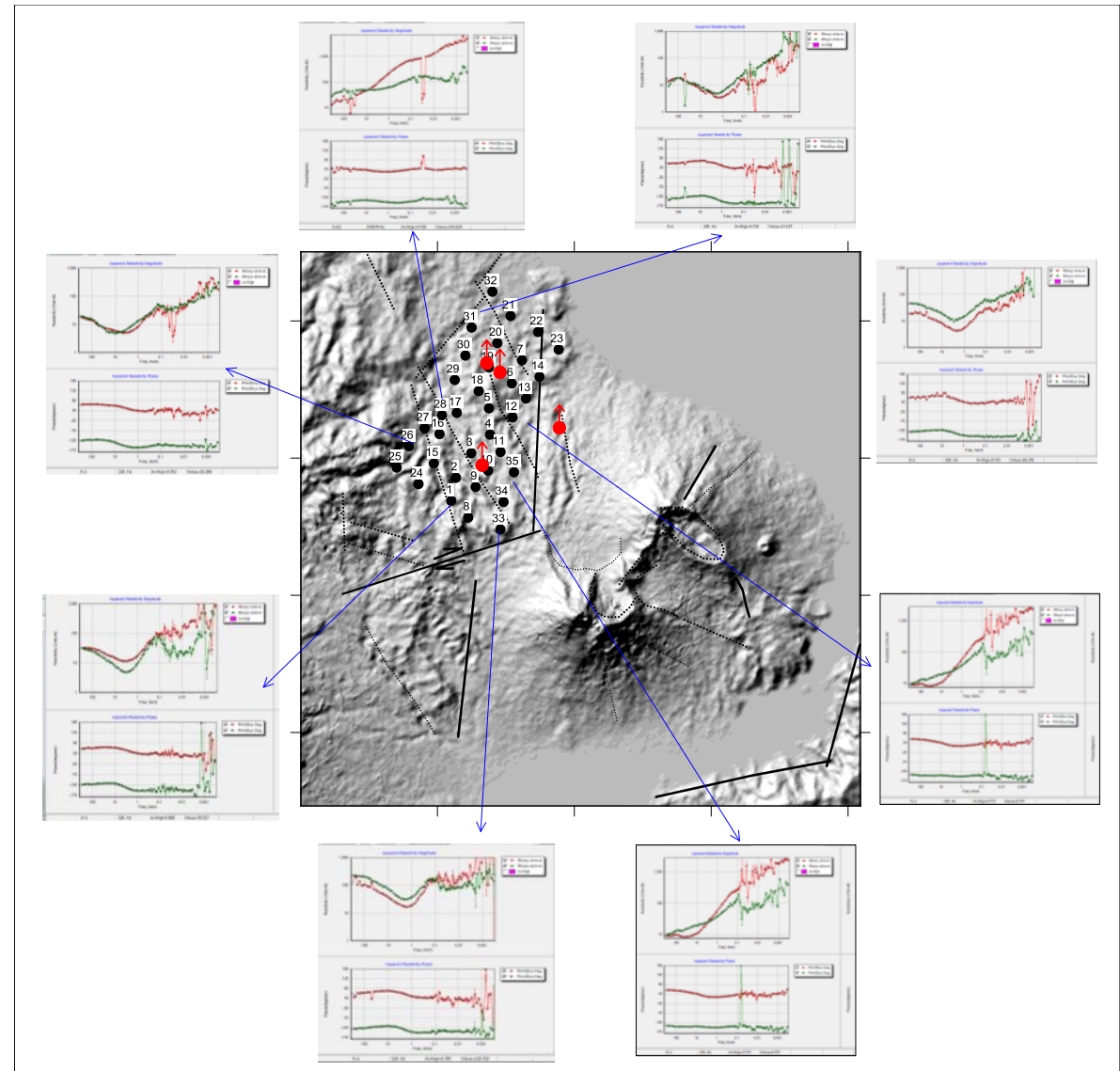

Gambar 4. Sebaran titik dan contoh data MT

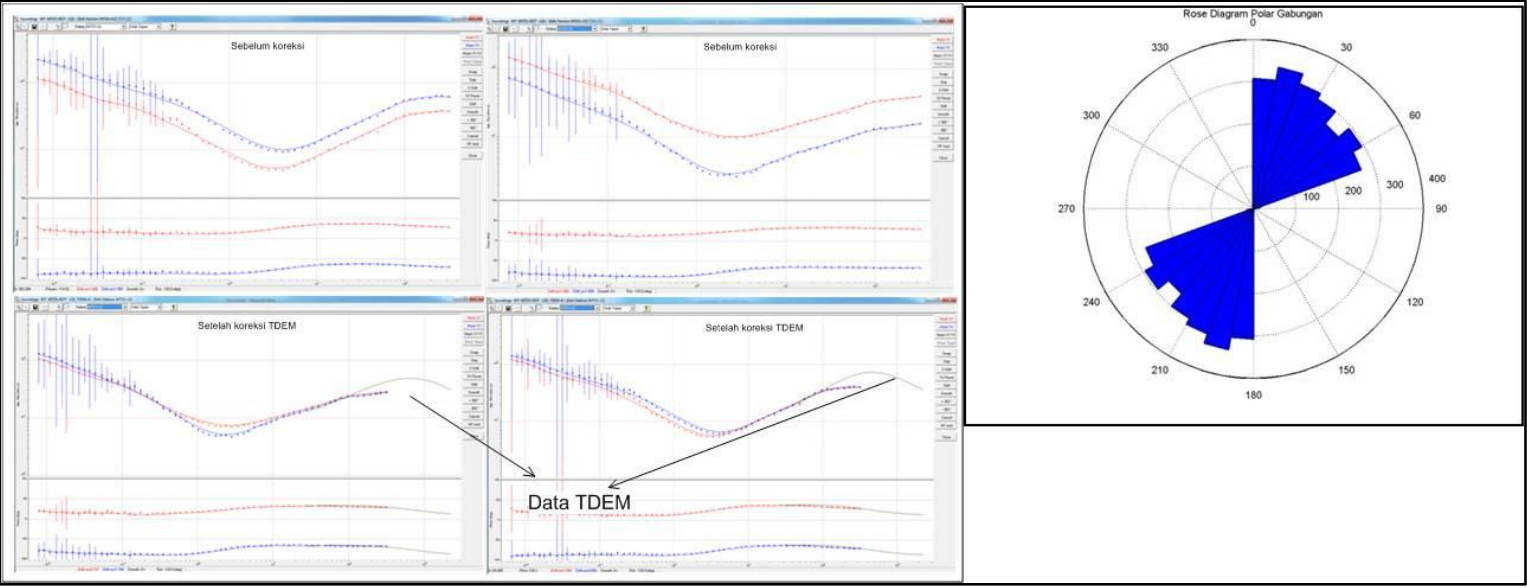

Gambar 5. Contoh data MT terkoreksi data TDEM dan penentuan arah rotasi. 

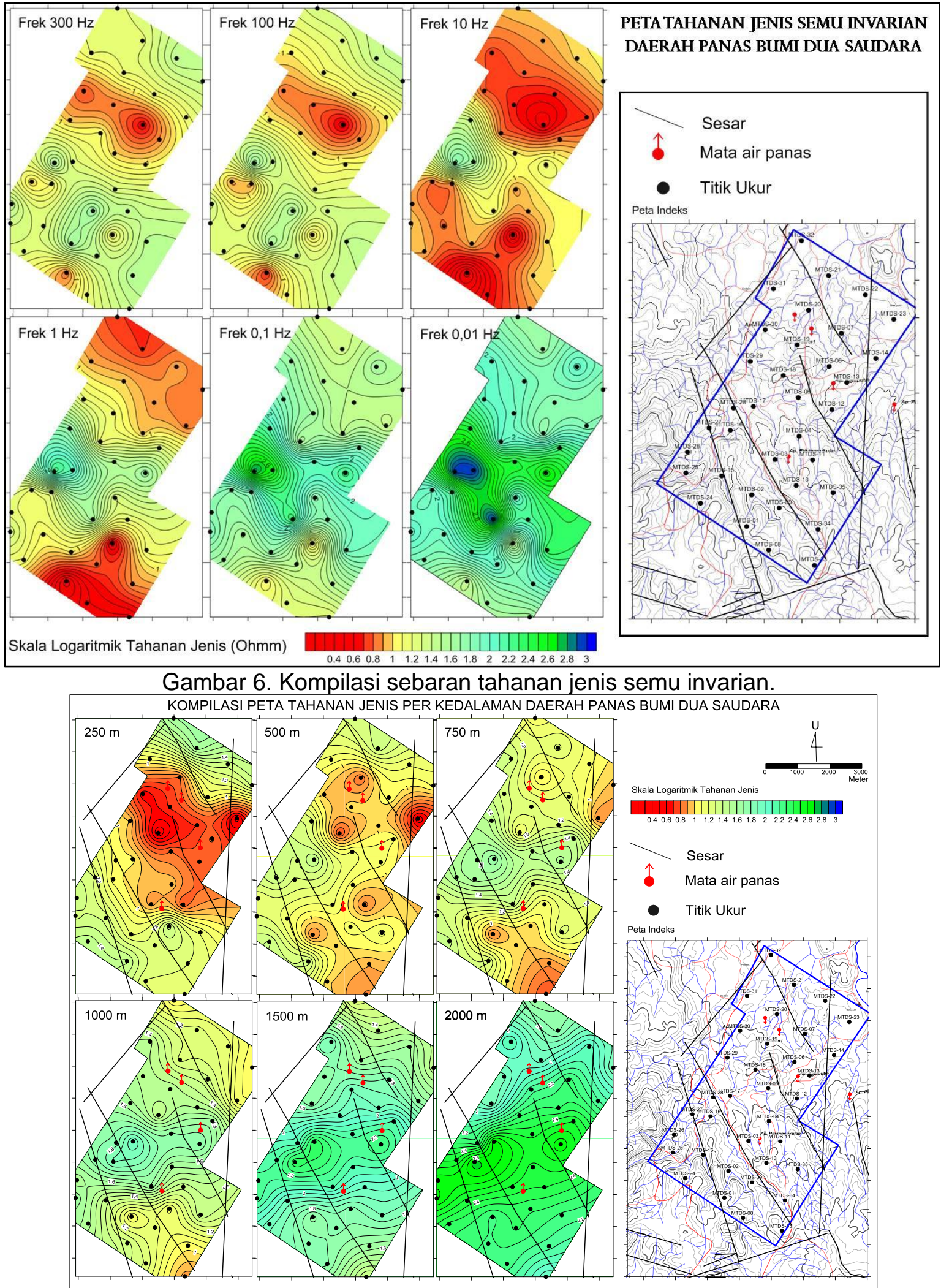

Gambar 7. Kompilasi sebaran model tahanan jenis

Pusat Sumber Daya Geologi - Badan Geologi - Kementrian Energi dan Sumber Daya Mineral Jalan Soekarno- Hatta No 444 Bandung Jawa Barat Website: psdg.geologi.esdm.go.id/ 


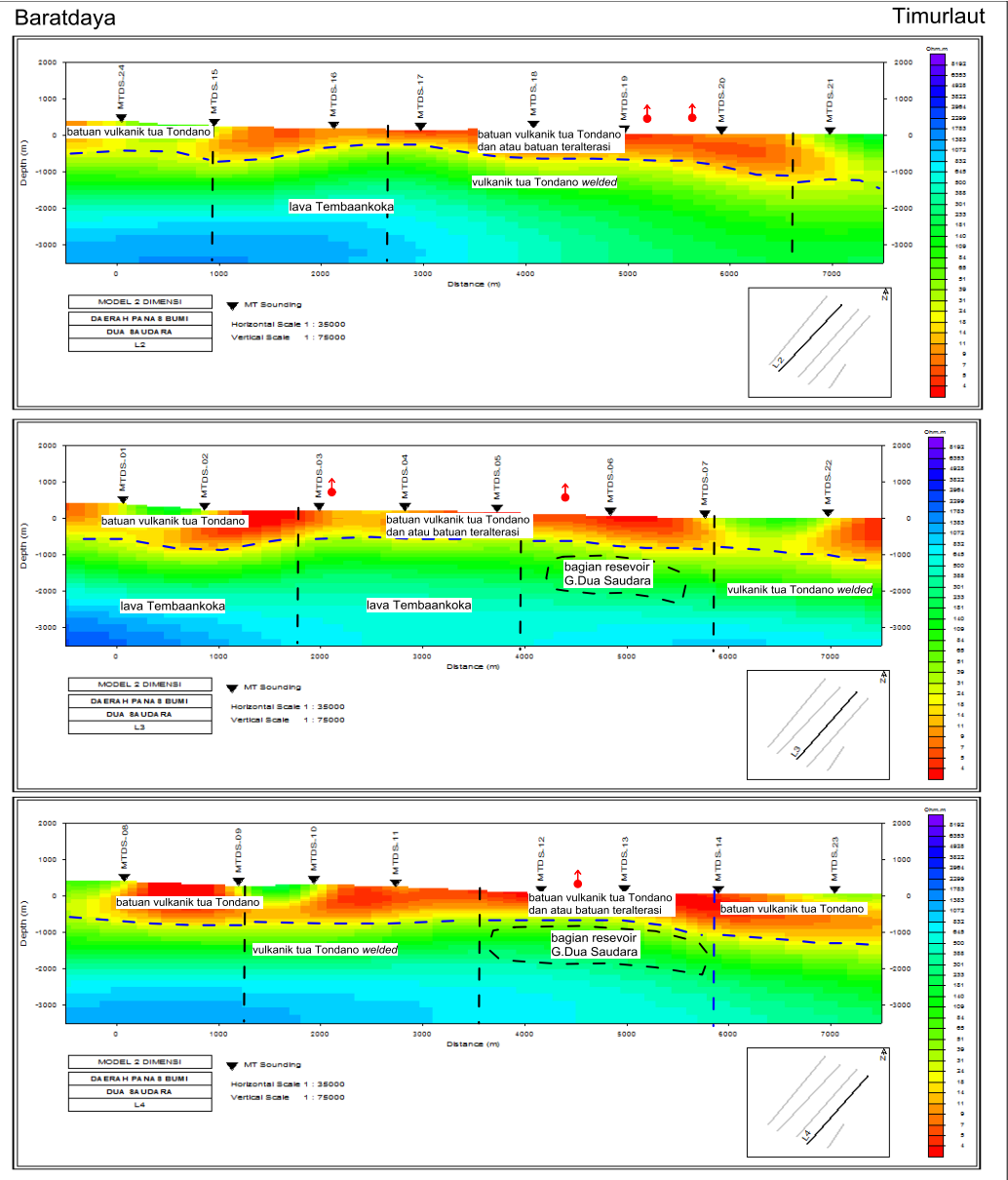

Gambar 8. Kompilasi penampang tahanan jenis 